Article

\title{
Sintering Mechanism, Microstructure Evolution, and Mechanical Properties of Ti-Added $\mathrm{Mo}_{2} \mathrm{FeB}_{2}$-Based Cermets
}

\author{
Yupeng Shen, Zhifu Huang *, Lei Zhang, Kemin Li, Zhen Cao, Peng Xiao and Yongxin Jian * \\ State Key Laboratory for Mechanical Behavior of Materials, Xi'an Jiaotong University, Xi'an 710049, China; \\ ilovehit3@126.com (Y.S.); xjtulei@outlook.com (L.Z.); kmin2015@stu.xjtu.edu.cn (K.L.); zcao_xjtu@163.com (Z.C.); \\ xiaopeng_0207@163.com (P.X.) \\ * Correspondence: zhifuhuangxjtu@163.com (Z.H.); yxjian@xjtu.edu.cn (Y.J.)
}

Received: 10 March 2020; Accepted: 14 April 2020; Published: 17 April 2020

\begin{abstract}
Four series of $\mathrm{Mo}_{2} \mathrm{FeB}_{2}$-based cermets with Ti contents between $0 \mathrm{wt} . \%$ and $1.5 \mathrm{wt} . \%$ in $0.5 \mathrm{wt} . \%$ increments were prepared by in situ reaction and liquid phase sintering technology. Influences of Ti on microstructure and mechanical properties of cermets were studied. It was found that $\mathrm{Ti}$ addition increases formation temperatures of liquid phases in liquid-phase stage. Ti atoms replace a fraction of Mo atoms in $\mathrm{Mo}_{2} \mathrm{FeB}_{2}$ and the solution of Ti atoms causes the $\mathrm{Mo}_{2} \mathrm{FeB}_{2}$ crystal to be equiaxed. In addition, the cermets with $1.0 \mathrm{wt} . \%$ Ti content exhibit the smallest particle size. The solution of Ti atoms in $\mathrm{Mo}_{2} \mathrm{FeB}_{2}$ promotes the transformation of $\mathrm{Mo}_{2} \mathrm{FeB}_{2}$ particles from elongated shape to equiaxed shape. With Ti content increasing from $0 \mathrm{wt} . \%$ to $1.5 \mathrm{wt} . \%$, the hardness and transverse rupture strength (TRS) first increase and then decrease. The maximum hardness and TRS occur with $1.0 \mathrm{wt} . \%$ Ti content. However, the fracture toughness decreases as Ti content increases. The cermets with $1.0 \mathrm{wt} . \% \mathrm{Ti}$ content show excellent comprehensive mechanical properties, and the hardness, fracture toughness, and TRS are HRA 89.5, $12.9 \mathrm{MPa} \cdot \mathrm{m}^{1 / 2}$, and $1612.6 \mathrm{MPa}$, respectively.
\end{abstract}

Keywords: $\mathrm{Mo}_{2} \mathrm{FeB}_{2}$-based cermets; $\mathrm{Ti}$ addition; sintering mechanism; microstructure; mechanical properties

\section{Introduction}

Borides possess high hardness and stable chemical properties. Thus, borides are a potential wear-resistant material and have been studied by many scholars [1-3]. Nevertheless, borides have intrinsic brittleness and poor sinterability. It is difficult to fabricate boride-based cermets due to these defects [4]. Reaction boronizing sintering is an efficient method to generate ternary borides by the reaction of binary borides and metals in the sintering process [5]. Ternary boride-based cermets exhibit low density, high fracture toughness, high hardness, excellent wear resistance and good corrosion resistance [6-10]. Therein, $\mathrm{Mo}_{2} \mathrm{FeB}_{2}$-based cermets have attracted relatively more attention for their low cost, little abrasion value, and excellent mechanical properties [4,11-13]. $\mathrm{Mo}_{2} \mathrm{FeB}_{2}$-based cermets are widely used in can tools and copper extrusion molds. Thus, $\mathrm{Mo}_{2} \mathrm{FeB}_{2}$-based cermets are widely studied [14-18].

$\mathrm{Mo}_{2} \mathrm{FeB}_{2}$-based cermets are composed with two phases: $\mathrm{Mo}_{2} \mathrm{FeB}_{2}$ and $\mathrm{Fe}$. Thus, $\mathrm{Mo}_{2} \mathrm{FeB}_{2}$-based cermets have the advantages of metal and ceramic [19]. Alloying is a common method to increase the mechanical properties of cermets. At present, $\mathrm{V}, \mathrm{Cr}$ and $\mathrm{Mn}$ are the most common doped elements. It was found that $\mathrm{V}$ atoms replace partial $\mathrm{Mo}$ atoms in $\mathrm{Mo}_{2} \mathrm{FeB}_{2}$, and decrease particle size of $\mathrm{Mo}_{2} \mathrm{FeB}_{2}$ [20]. The previous work revealed that $\mathrm{Mn}$ atoms replace a fraction of Mo atoms in $\mathrm{Mo}_{2} \mathrm{FeB}_{2}$ particles, and the addition of $\mathrm{Mn}$ increases the wettability of liquid phase on $\mathrm{Mo}_{2} \mathrm{FeB}_{2}$ 
particles [21-23]. It was reported that $\mathrm{Cr}$ atoms replace a fraction of $\mathrm{Mo}$ atoms in $\mathrm{Mo}_{2} \mathrm{FeB}_{2}$ particles, and the addition of $\mathrm{Cr}$ decreases the particle size and increases the sphericity of $\mathrm{Mo}_{2} \mathrm{FeB}_{2}$ hard phase [24,25]. Through analyses, a general rule can be obtained that doped elements replace partial Mo atoms in $\mathrm{Mo}_{2} \mathrm{FeB}_{2}$ hard phase, since the atomic radii of $\mathrm{V}(1.92 \AA)$, $\mathrm{Mn}(1.79 \AA)$, and $\mathrm{Cr}(1.85 \AA)$ are close to the atomic radius of $\mathrm{Mo}(2.01 \AA)$ [26]. It is natural to assume that partial Mo atoms in $\mathrm{Mo}_{2} \mathrm{FeB}_{2}$ hard phase can be replaced by other atoms which have similar atomic radii. According to periodic table, the atomic radius of $\mathrm{Ti}$ is $2.00 \AA$ and it is very close to the atomic radius of Mo. Thus, Ti may be a new doped element which can replace partial Mo atoms. The $\mathrm{Mo}_{2} \mathrm{FeB}_{2}$ hard phase shows a structure of $\mathrm{U}_{3} \mathrm{Si}_{2}$ and belongs to a tetragonal system [27-29]. Considering the strong bonding existing within $\mathrm{Mo}_{2} \mathrm{FeB}_{2}$ that contributes to its incredible properties [28-31], the substitution of atoms may have an important effect on the performance of cermets. To date, however, adding $\mathrm{Ti}$ in $\mathrm{Mo}_{2} \mathrm{FeB}_{2}$-based cermets is barely reported.

Herein, four series of cermet samples with $x \operatorname{Ti}(x=0,0.5,1.0,1.5$, wt.\%) contents were prepared by in situ reaction and liquid phase sintering technology. Influences of Ti on microstructure and mechanical properties of cermets are studied in detail.

\section{Materials and Experimental Procedure}

\subsection{Materials}

In this paper, $\mathrm{Mo}, \mathrm{FeB}, \mathrm{Fe}$ and $\mathrm{Ti}$ powders, which are available on the market, were used as raw materials. Figure 1 shows the micromorphologies of the raw powders. It can be seen that the shape of Fe and Mo powders are spherical. However, the shape of Ti and FeB powders are irregular. Table 1 shows characteristics of the raw materials. The nominal compositions used in this work was $\mathrm{Fe}_{46.5-\mathrm{x}}$ $\mathrm{Mo}_{47.5} \mathrm{~B}_{6} \mathrm{Ti}_{\mathrm{x}}(\mathrm{x}=0,0.5,1.0,1.5, \mathrm{wt} . \%)$.
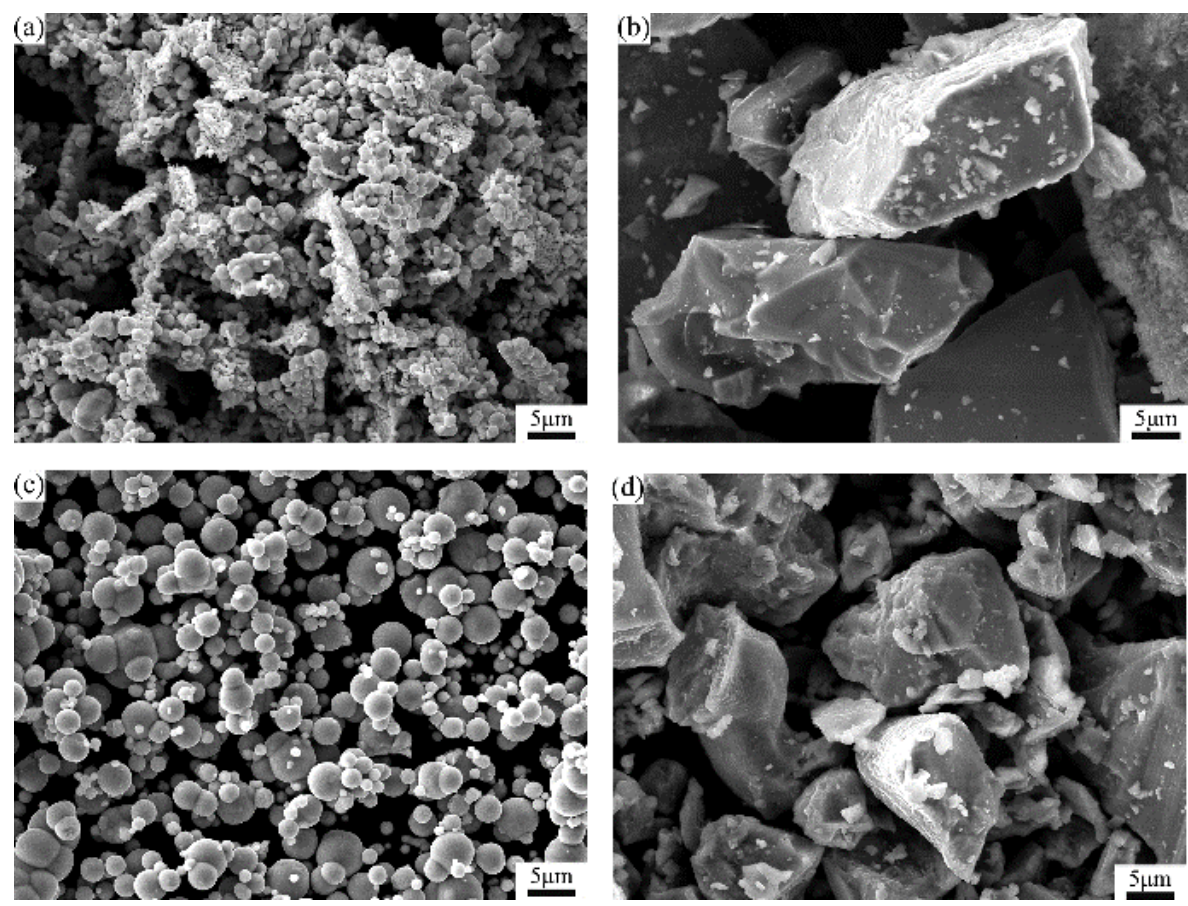

Figure 1. Scanning electron microscopy (SEM) micrographs of raw powders: (a) Mo; (b) FeB; (c) Fe; (d) Ti. 
Table 1. Characteristics of raw materials.

\begin{tabular}{cccc}
\hline Powder & Average Particle Size $(\mu \mathrm{m})$ & Chemical Composition $(w t . \%)$ & Manufacturer \\
\hline $\mathrm{Mo}$ & 2 & $\mathrm{Mo} \geq 99.95, \mathrm{Fe}<0.005, \mathrm{Si}<0.002$ & Changsha Tianjiu Metal \\
$\mathrm{Ti}$ & 24 & $\mathrm{Ti} \geq 99.50, \mathrm{O} \leq 0.25, \mathrm{Si} \leq 0.02$ & Material Corp., Ltd. \\
$\mathrm{Fe}$ & 5 & $\mathrm{Fe} \geq 99.81, \mathrm{C}<0.015, \mathrm{O}<0.16$ & Changsha, China \\
$\mathrm{FeB}$ & 45 & $\mathrm{~B}=20.05, \mathrm{Si}<0.36, \mathrm{C}<0.36$ & \\
\hline
\end{tabular}

\subsection{Fabrication Process}

Raw powders, which were weighed according to above proportion, were put into a planetary ball mill for grinding. After that, the grated powders were dried using a rotary evaporator. A semi-automatic press was used to press the powders into green compacts. Afterwards, the samples were placed in vacuum sintering furnace for sintering. Figure S1 shows the sintering process curve (Supplementary Materials).

\subsection{Characterization}

The phase-transition temperatures of samples were determined by differential scanning calorimetry (DSC, STA 449F5, NETZSCH, Bavaria, Germany). The samples were heated from room temperature to $1300{ }^{\circ} \mathrm{C}$. The phase analyses were performed via X-ray diffraction analysis (XRD, D8 Advance, Bruker, Billerica, MA, USA) using $\mathrm{Cu} \mathrm{K} \alpha$ radiation at $40 \mathrm{kV}$ as an X-ray source. Scanning electron microscopy (SEM, SU3500, Hitachi, Tokyo, Japan) was used to observe the microstructure of $\mathrm{Mo}_{2} \mathrm{FeB}_{2}$-based cermets and bending fracture surface morphology. The particle size and sphericity of $\mathrm{Mo}_{2} \mathrm{FeB}_{2}$ hard phase were measured via Image analysis software (Image Pro Plus, Version 6.0, Media Cybernetics, Rockville, MD, USA) [32-34]. The measurement methods and calculation formulas are provided in supplementary information. ImageJ software was utilized to calculate the volume fraction of $\mathrm{Mo}_{2} \mathrm{FeB}_{2}$ particles and 20 SEM micrographs were used for each group of specimens to obtain statistical results. The relative densities of cermets were determined as per Archimedes technique [35]. The calculation formula is provided in supplementary information. The distribution of various elements in cermets was determined by electron probe microanalysis (EPMA, JXA-8230, JEOL, Tokyo, Japan).

The hardness of $\mathrm{Mo}_{2} \mathrm{FeB}_{2}$-based cermets was measured under a hardness tester (MX1000, Jinan, China), and each sample was measured at least 5 times. Fracture toughness $\left(\mathrm{K}_{\mathrm{IC}}\right)$ and transverse rupture strength (TRS) tests of $\mathrm{Mo}_{2} \mathrm{FeB}_{2}$-based cermets at room temperature were conducted using a three-point bend test [35], whose measurement methods and calculation formulas are provided in supplementary information.

\section{Results and Discussion}

\subsection{Sintering Mechanism}

DSC curves of powders with $0 \mathrm{wt} . \%$ and $1.0 \mathrm{wt} . \%$ Ti contents are presented in Figure 2. It can be seen that from Figure 2, the trends of the two curves are basically the same, and both of the thermal curves have two endothermic peaks. However, the difference is that the temperatures of forming liquid phases are changed. The endothermic peaks of milled powders with $1.0 \mathrm{wt} . \%$ Ti content occur at higher temperature compared to that without Ti. With the sintering temperature increasing, $\mathrm{L}_{1}$ and $\mathrm{L}_{2}$ occur as follows [36].

$$
\begin{gathered}
\gamma-\mathrm{Fe}+\mathrm{Fe}_{2} \mathrm{~B} \rightarrow \mathrm{L}_{1} \\
\gamma-\mathrm{Fe}+\mathrm{L}_{1}+\mathrm{Mo}_{2} \mathrm{FeB}_{2} \rightarrow \mathrm{L}_{2}+\mathrm{Mo}_{2} \mathrm{FeB}_{2}
\end{gathered}
$$




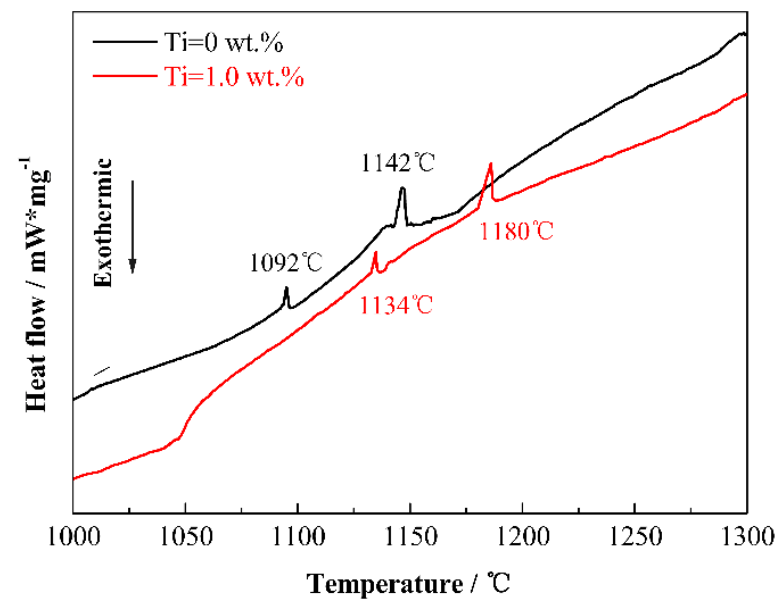

Figure 2. DSC curves of powders with 0 and $1.0 \mathrm{wt} . \%$ Ti contents.

It can be speculated from Figure 2 that Ti addition increases reaction temperatures of liquid phases. It was reported that the solid solubility of Ti in $\gamma-\mathrm{Fe}$ is very low $[37,38]$, and it is not conducive to the inter-diffusion among elements [39]. Thus, Ti addition can inhibit the inter-diffusion in the sintering, as a result, the liquid-phase reactions take place at a higher temperature. It is worth noting that the relative density and particle size of cermets are affected by two liquid-phase reactions. As per the literature $[16,40,41]$, grain rearrangement of $\mathrm{Mo}_{2} \mathrm{FeB}_{2}$ particles occurs in $\mathrm{L}_{1}$ such that the densification of $\mathrm{Mo}_{2} \mathrm{FeB}_{2}$-based cermets increases rapidly. On the other hand, the growth of $\mathrm{Mo}_{2} \mathrm{FeB}_{2}$ particles is mainly achieved via dissolution and precipitation of $\mathrm{Mo}_{2} \mathrm{FeB}_{2}$ grains in $\mathrm{L}_{2}$. As a result, the increase of reaction temperature of $\mathrm{L}_{1}$ is not conducive to the densification of cermets with Ti addition. However, the increase of forming temperature of $\mathrm{L}_{2}$ contributes to grain refinement of cermets. The influence mechanism of Ti will be systematically described below.

\subsection{Microstructure Evolution}

Figure 3 shows XRD patterns of $\mathrm{Mo}_{2} \mathrm{FeB}_{2}$-based cermets with various Ti contents. It can be seen that from Figure $3 a$, cermets with various Ti contents have the same phase compositions. The main phases are $\mathrm{Mo}_{2} \mathrm{FeB}_{2}$ (JCPDS 89-3630) and Fe (JCPDS 87-0722). Figure $3 \mathrm{~b}$ shows the local XRD curves with diffraction angle between $42^{\circ}$ and $46^{\circ}$. It can be seen that from Figure $3 \mathrm{~b}$, with the increase of Ti content, the diffraction angles of $\mathrm{Mo}_{2} \mathrm{FeB}_{2}$ gradually increase. For instance, the diffraction angle of main peak (201) of $\mathrm{Mo}_{2} \mathrm{FeB}_{2}$ hard phase without $\mathrm{Ti}$ is $42.659^{\circ}$ while that with $1.5 \mathrm{wt} . \%$ content $\mathrm{Ti}$ is $42.754^{\circ}$. The increase of diffraction angle means the shrinkage of the lattice of $\mathrm{Mo}_{2} \mathrm{FeB}_{2}$. The shrinkage of the lattice is caused by the substitution of atoms (Ti) with smaller radii for atoms (Mo) with larger radius, which is consistent with what is envisaged in the experiment.

Figure 4 shows the lattice constants of $\mathrm{Mo}_{2} \mathrm{FeB}_{2}$ crystal with different Ti contents. As shown, the lattice constant a and $\mathrm{c}$ of $\mathrm{Mo}_{2} \mathrm{FeB}_{2}$ crystal both decrease with increasing Ti content. The lattice constant a of $\mathrm{Mo}_{2} \mathrm{FeB}_{2}$ decreases from $5.7750 \AA$ to $5.7562 \AA$ and the lattice constant c decreases from $3.1450 \AA$ to $3.1394 \AA$, which is consistent with diffraction peaks shift of $\mathrm{Mo}_{2} \mathrm{FeB}_{2}$ hard phase shown in Figure 3. However, the c/a ratio gradually increases from 0.5446 to 0.5454 . The c/a approaching 1 indicates that the crystal has become equiaxed. Thus, the solution of $\mathrm{Ti}$ into $\mathrm{Mo}_{2} \mathrm{FeB}_{2}$-based cermets causes $\mathrm{Mo}_{2} \mathrm{FeB}_{2}$ crystal to be equiaxed.

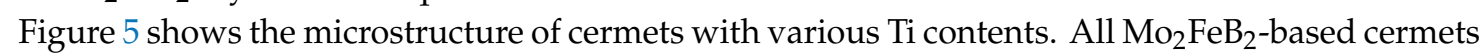
are composed with two phases: $\mathrm{Mo}_{2} \mathrm{FeB}_{2}$ and $\mathrm{Fe}$. The results are consistent with XRD analyses shown in Figure 3. For cermets with Ti content between $0 \mathrm{wt} . \%$ and $1.0 \mathrm{wt} . \%, \mathrm{Mo}_{2} \mathrm{FeB}_{2}$ particles are equally distributed in the cermets. Nevertheless, aggregation of $\mathrm{Mo}_{2} \mathrm{FeB}_{2}$ hard phases occurs when Ti content reaches $1.5 \mathrm{wt} . \%$. 

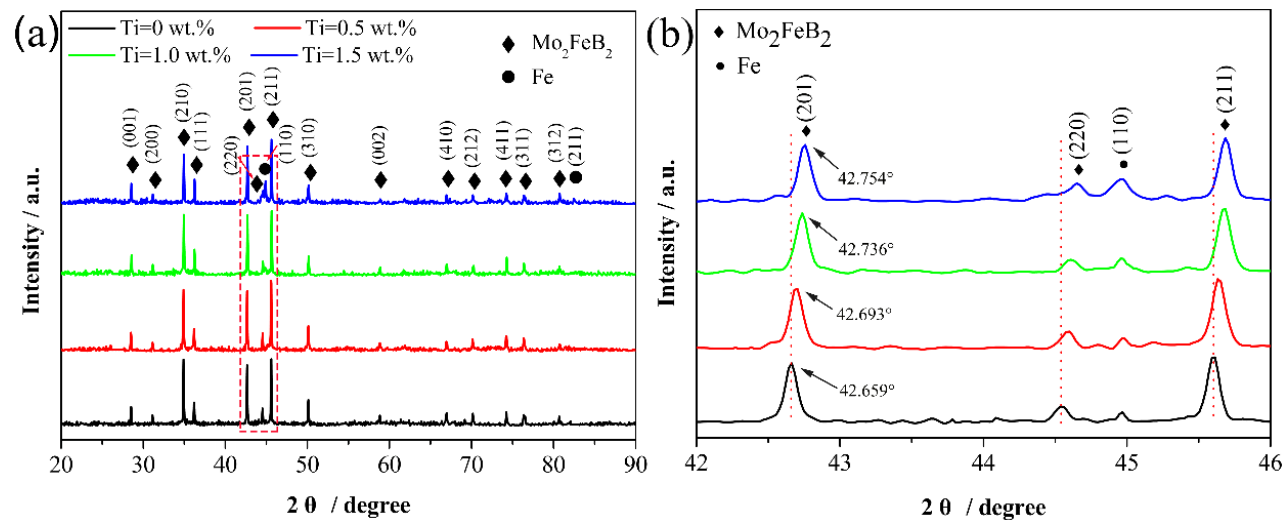

Figure 3. XRD patterns of $\mathrm{Mo}_{2} \mathrm{FeB}_{2}$-based cermets with various Ti contents: (a) integral XRD patterns; (b) Local XRD patterns range from $42^{\circ}$ to $46^{\circ}$.

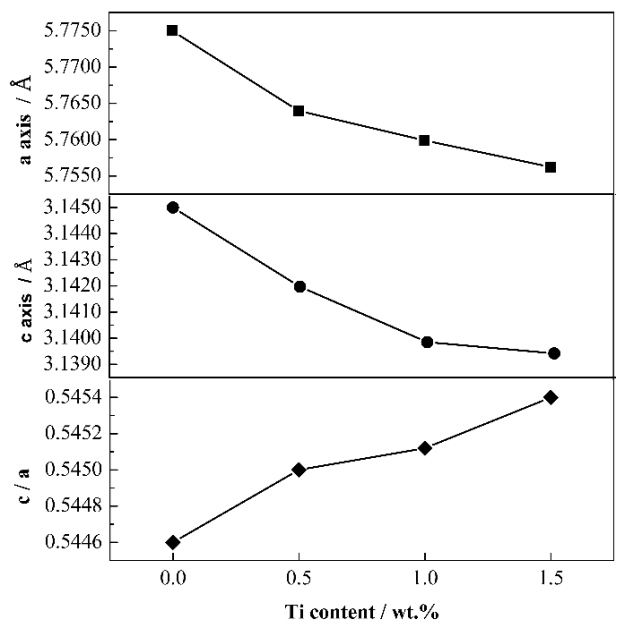

Figure 4. Lattice constants of $\mathrm{Mo}_{2} \mathrm{FeB}_{2}$ crystal with different Ti contents.
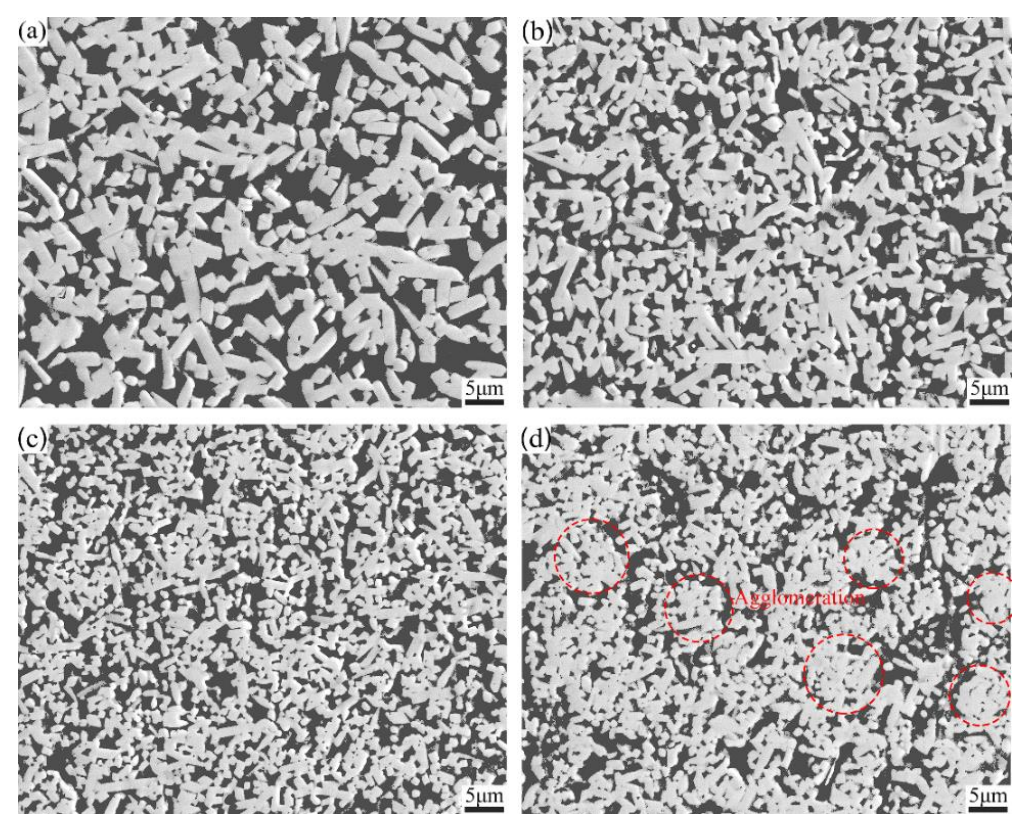

Figure 5. Microstructure of $\mathrm{Mo}_{2} \mathrm{FeB}_{2}$-based cermets with various Ti contents: (a) 0 wt. \%; (b) 0.5 wt.\%; (c) 1.0 wt. \%; (d) 1.5 wt. \%. 
Moreover, the particle size of the $\mathrm{Mo}_{2} \mathrm{FeB}_{2}$ hard phase varies with Ti addition. With the increase of Ti content, the particle size of $\mathrm{Mo}_{2} \mathrm{FeB}_{2}$ hard phase first decreases and then increases. The cermets exhibit the smallest particle size when Ti content is $1.0 \mathrm{wt} . \%$. In order to further analyze the variation trend of particle size of the $\mathrm{Mo}_{2} \mathrm{FeB}_{2}$ hard phase, the statistical results of particle size distribution of $\mathrm{Mo}_{2} \mathrm{FeB}_{2}$ are presented in Figure 6 and will be discussed in detail below. As shown in Figure 6, with the increase of Ti content from $0 \mathrm{wt} . \%$ to $1.0 \mathrm{wt} . \%$, the range of particle size distribution becomes narrower and then becomes wider at Ti content of $1.5 \mathrm{wt} . \%$. In addition, the average particle size of $\mathrm{Mo}_{2} \mathrm{FeB}_{2}$-based cermets first decreases and then increases. The minimum average particle size of $1.42 \mu \mathrm{m}$ is obtained when Ti content is $1.0 \mathrm{wt} . \%$. The causes of $\mathrm{Mo}_{2} \mathrm{FeB}_{2}$ particle size variation are complex. When Ti content is between $0 \mathrm{wt} . \%$ and $1.0 \mathrm{wt} . \%$, the amount of liquid phase is enough in high-temperature phase. The growth mechanism of $\mathrm{Mo}_{2} \mathrm{FeB}_{2}$ particles is solution-precipitation [36]. Thus, the particle size of $\mathrm{Mo}_{2} \mathrm{FeB}_{2}$ particles depends on the solution-precipitation reaction. As a result of the addition of $\mathrm{Ti}$, the formation temperature of $\mathrm{L}_{2}$ increases, which is harmful to the growth of $\mathrm{Mo}_{2} \mathrm{FeB}_{2}$ particles. Therefore, the particle size of $\mathrm{Mo}_{2} \mathrm{FeB}_{2}$ particle decreases. When Ti content is $1.5 \mathrm{wt} . \%$, the amount of liquid phase decreases further. The distance among $\mathrm{Mo}_{2} \mathrm{FeB}_{2}$ grains becomes smaller so as to $\mathrm{Mo}_{2} \mathrm{FeB}_{2}$ grains tend to merge and grow [4,17], and the $\mathrm{Mo}_{2} \mathrm{FeB}_{2}$ grains no longer grow through the solution-precipitation mechanism. Thus, the $\mathrm{Mo}_{2} \mathrm{FeB}_{2}$ will be coarser as particles aggregate.
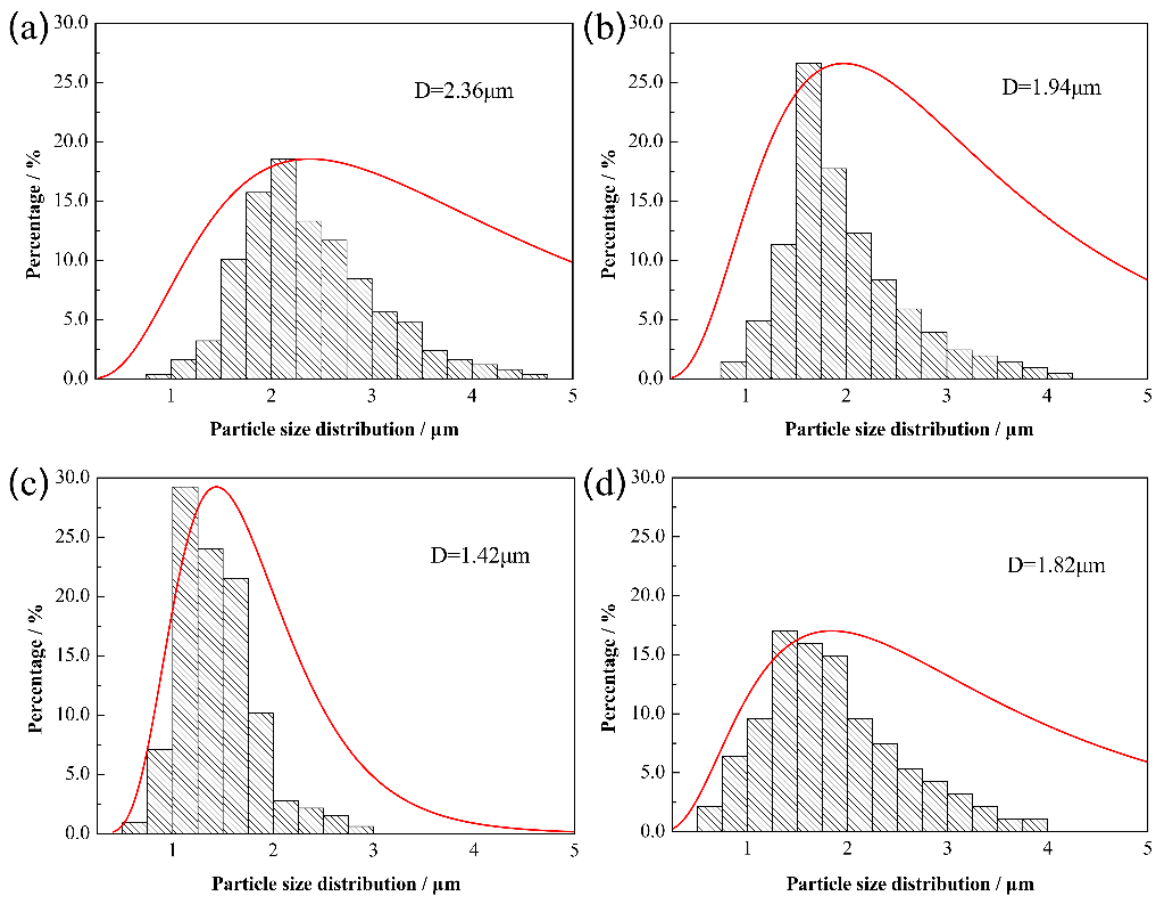

Figure 6. Particle size distribution of $\mathrm{Mo}_{2} \mathrm{FeB}_{2}$ hard phase with different Ti contents: (a) 0 wt. $\%$; (b) 0.5 wt. \%; (c) 1.0 wt. \%; (d) 1.5 wt.\%.

Figure 7 shows the sphericity distribution of $\mathrm{Mo}_{2} \mathrm{FeB}_{2}$ hard phase with various Ti contents. It can be seen that from Figure 7, the values of lower and upper limits of sphericity distribution range gradually increase with $\mathrm{Ti}$ content increasing, while the range of sphericity distribution becomes narrower. And the average sphericity increases from 0.658 to 0.725 . The closer the sphericity is to 1 , the more equiaxed the $\mathrm{Mo}_{2} \mathrm{FeB}_{2}$ particles are, indicating that the shape of $\mathrm{Mo}_{2} \mathrm{FeB}_{2}$ particles gradually becomes equiaxed with Ti content increasing. It was reported that the morphologies of particles are influenced by their surface energies [42,43]. Thus, due to the addition of $\mathrm{Ti}$, the surface energies of $\mathrm{Mo}_{2} \mathrm{FeB}_{2}$ particles may be changed. Ti addition reduces the preferred orientation of $\mathrm{Mo}_{2} \mathrm{FeB}_{2}$ particles. Takagi and $\mathrm{Yu}[15,20]$ reported that the shape of $\mathrm{Mo}_{2} \mathrm{FeB}_{2}$ particles depends on the degree of grain 
orientation. Thereby, as per the calculation results for lattice constant of $\mathrm{Mo}_{2} \mathrm{FeB}_{2}$ crystal shown in Figure 4 , the phenomenon of equiaxed particles can be reasonably explained.
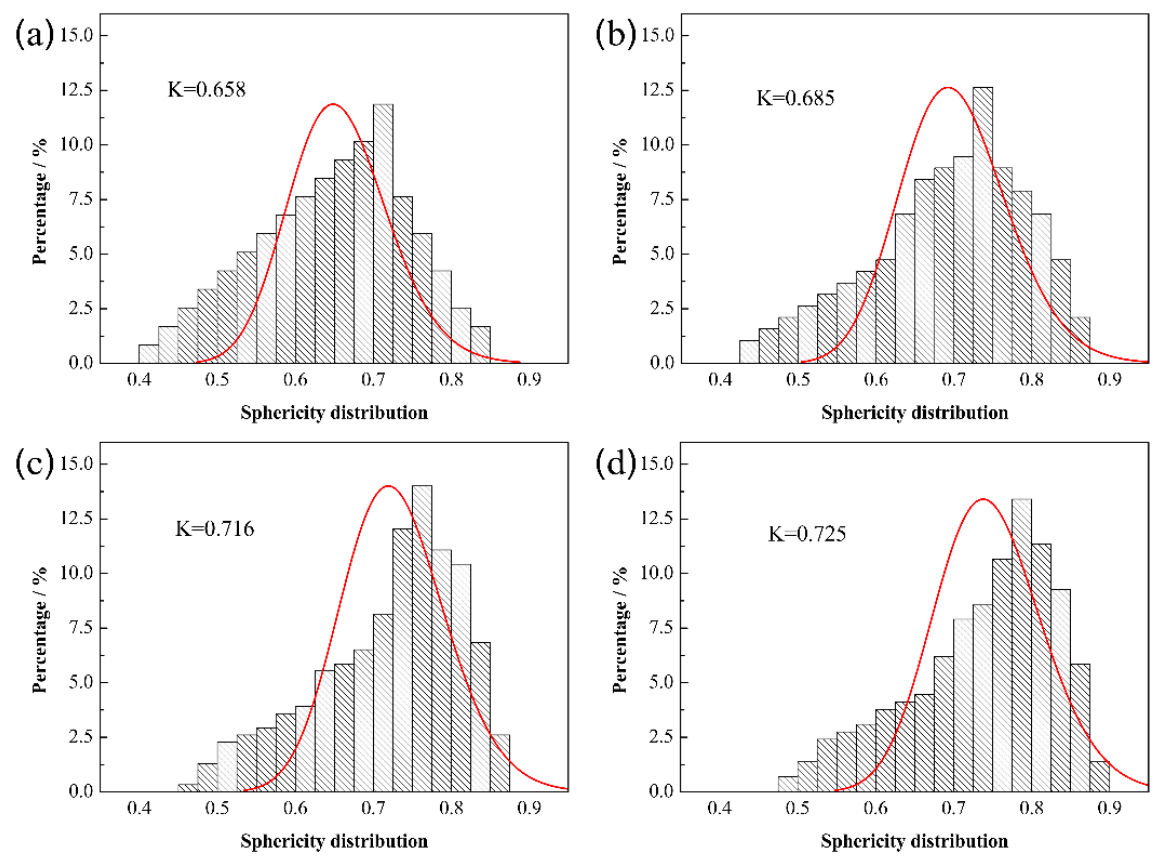

Figure 7. Sphericity distribution of $\mathrm{Mo}_{2} \mathrm{FeB}_{2}$ hard phase with different Ti contents: (a) 0 wt. $\%$; (b) 0.5 wt. \%; (c) 1.0 wt.\%; (d) 1.5 wt.\%.

Figure 8 shows the volume fraction of $\mathrm{Mo}_{2} \mathrm{FeB}_{2}$ particles and relative density of $\mathrm{Mo}_{2} \mathrm{FeB}_{2}$-based cermets with various Ti contents. As Ti content increases from $0 \mathrm{wt} . \%$ to $1.5 \mathrm{wt} . \%$, the volume fraction of $\mathrm{Mo}_{2} \mathrm{FeB}_{2}$ hard phase increases. The reason is that Fe content decreases with Ti content increasing, resulting in the increase of the content of $\mathrm{Mo}_{2} \mathrm{FeB}_{2}$. Nevertheless, it can also be seen that the relative density of cermets shows the opposite trend. The relative density keeps falling with Ti content increasing. There are two reasons for the drop in relative density. The first reason is that the increase of Ti content leads to the decrease of liquid phase in cermets. The lesser liquid phase does not flow well enough to fill the holes efficiently. The second reason is that the increase of formation temperature of $\mathrm{L}_{1}$ is not conducive to the densification of cermets due to Ti addition. Thus, the relative density of cermets decreases.

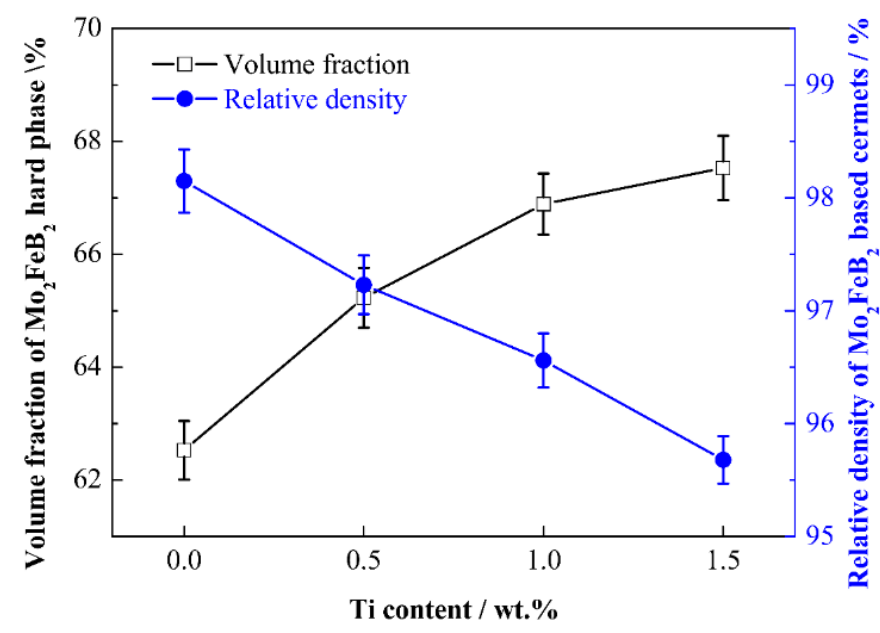

Figure 8. Volume fraction of $\mathrm{Mo}_{2} \mathrm{FeB}_{2}$ hard phase and relative density of $\mathrm{Mo}_{2} \mathrm{FeB}_{2}$-based cermets with various Ti contents. 
EPMA analyses of $\mathrm{Mo}_{2} \mathrm{FeB}_{2}$-based cermets with $1.0 \mathrm{wt}$ \% Ti content are presented in Figure 9. As shown, the distribution of Mo, B and Ti are mainly the same. However, Fe has the opposite trend. It can be concluded that, $\mathrm{Ti}$, Mo, and $\mathrm{B}$ are mainly distributed in the $\mathrm{Mo}_{2} \mathrm{FeB}_{2}$ hard phase while Fe is mainly distributed in the binder phase.
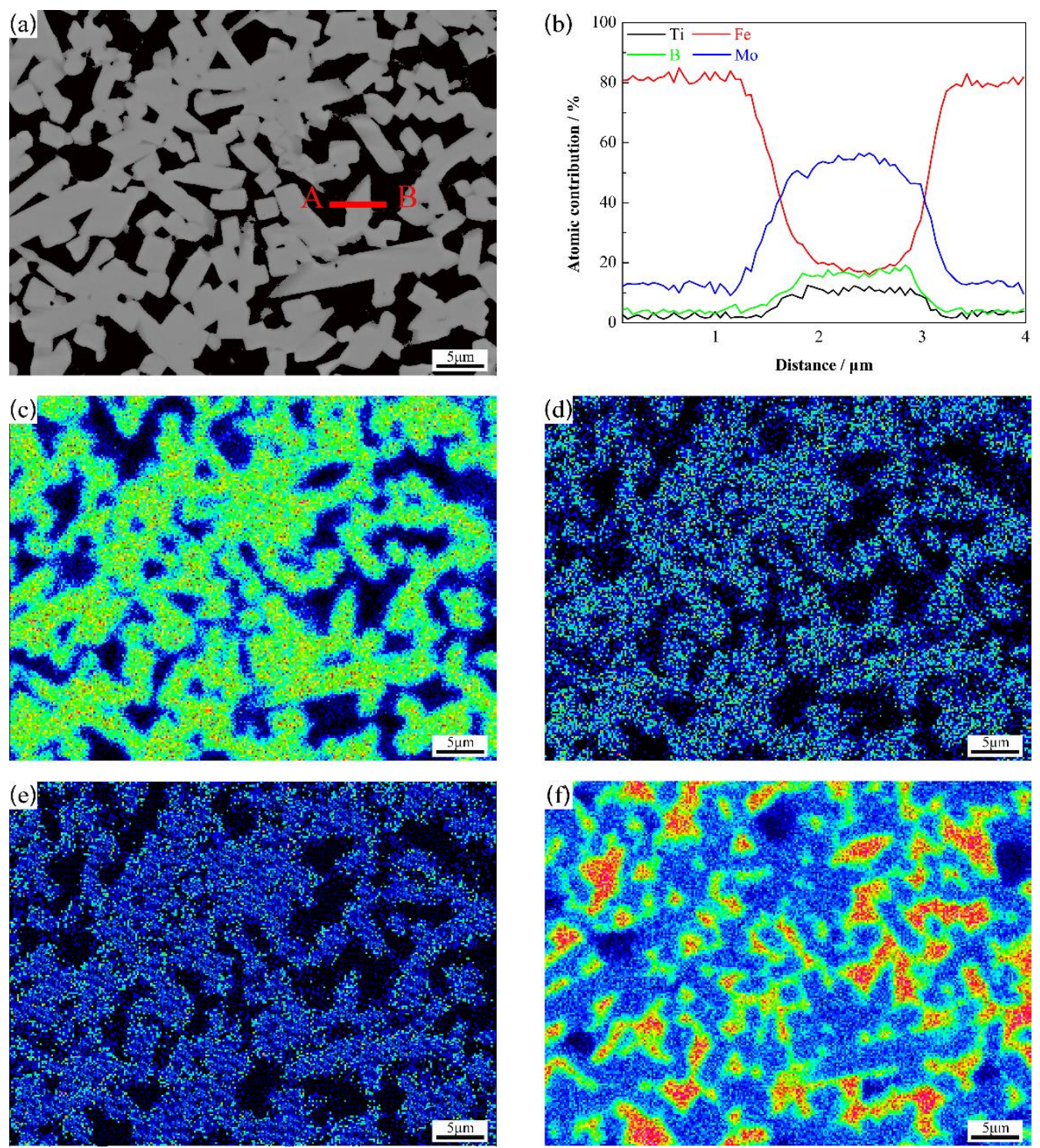

Figure 9. Electron probe microanalysis (EPMA) analyses of $\mathrm{Mo}_{2} \mathrm{FeB}_{2}$-based cermets with $1.0 \mathrm{wt}$. \% Ti content: (a) SEM picture; (b) line scan analyses along line segment AB of (a); (c-f) mapping of Mo, B, $\mathrm{Ti}$ and Fe element of (a), respectively.

The chemical compositions of the $\mathrm{Mo}_{2} \mathrm{FeB}_{2}$ hard phase with different Ti contents are measured by EPMA, as shown in Table 2. Fe, Ti and $\mathrm{B}$ content in $\mathrm{Mo}_{2} \mathrm{FeB}_{2}$ all increase as Ti content increases, while the Mo content decreases. Therefore, Ti atoms are supposed to replace partial Mo atoms in $\mathrm{Mo}_{2} \mathrm{FeB}_{2}$. The results are consistent with the analyses above. 
Table 2. Chemical compositions of $\mathrm{Mo}_{2} \mathrm{FeB}_{2}$ hard phase with different Ti contents (wt.\%).

\begin{tabular}{ccccc}
\hline Ti Content & Ti & Fe & Mo & B \\
\hline 0 & 0 & 20.74 & 71.11 & 8.15 \\
0.5 & 0.72 & 20.94 & 70.13 & 8.21 \\
1.0 & 1.38 & 21.57 & 68.78 & 8.27 \\
1.5 & 1.89 & 21.87 & 67.91 & 8.33 \\
\hline
\end{tabular}

\subsection{Mechanical Properties}

Hardness and fracture toughness of cermets with various Ti contents are shown in Figure 10. As shown, with the increase of Ti content, the hardness of $\mathrm{Mo}_{2} \mathrm{FeB}_{2}$-based cermets first increases and then decreases. The maximum hardness of $89.5 \mathrm{HRA}$ is obtained when Ti content is $1.0 \mathrm{wt} . \%$. As is well known, high volume fraction of hard phase, small particle size, and high relative density in cermets are beneficial to the improvement of hardness. In this work, with Ti content increasing from $0 \mathrm{wt} . \%$ to $1.0 \mathrm{wt} . \%$, the relative amount of $\mathrm{Mo}_{2} \mathrm{FeB}_{2}$ hard phase increases and the particle size of $\mathrm{Mo}_{2} \mathrm{FeB}_{2}$ particles decreases, resulting in positive effects on the improvement of hardness. However, the drop of relative density is harmful to hardness. Therefore, the hardness of $\mathrm{Mo}_{2} \mathrm{FeB}_{2}$-based cermets increases with the increase of Ti content. When Ti content is $1.5 \mathrm{wt} . \%$, the increase of relative amount of $\mathrm{Mo}_{2} \mathrm{FeB}_{2}$ hard phase is conducive to the improvement of hardness, while particle size of $\mathrm{Mo}_{2} \mathrm{FeB}_{2}$ particles increases and relative density decreases further. Adverse effects predominate in the increase of hardness. Thus, the hardness of $\mathrm{Mo}_{2} \mathrm{FeB}_{2}$-based cermets is greatly reduced when Ti content is $1.5 \mathrm{wt} . \%$.

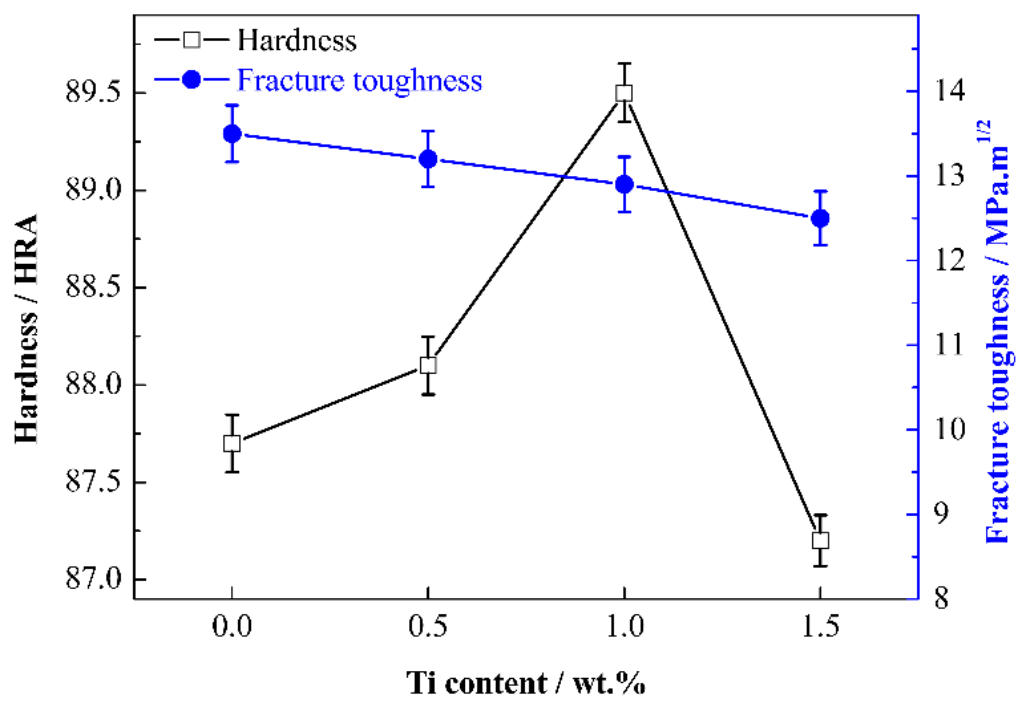

Figure 10. Hardness and fracture toughness of $\mathrm{Mo}_{2} \mathrm{FeB}_{2}$-based cermets with various Ti contents.

With the increase of Ti content from $0 \mathrm{wt} . \%$ to $1.5 \mathrm{wt} . \%$, the fracture toughness of $\mathrm{Mo}_{2} \mathrm{FeB}_{2}$-based cermets keeps going down, while the decline scope is small. Because $\mathrm{Mo}_{2} \mathrm{FeB}_{2}$ hard phase is brittle, the fracture toughness of $\mathrm{Mo}_{2} \mathrm{FeB}_{2}$-based cermets is mainly provided by Fe binder phase. Thus, the high content of Fe binder phase is beneficial to the increase of fracture toughness of cermets. The fracture toughness of cermets is also affected by factors like relative density of cermets and shape of $\mathrm{Mo}_{2} \mathrm{FeB}_{2}$ particles. Both the high relative density of $\mathrm{Mo}_{2} \mathrm{FeB}_{2}$-based cermets and equiaxed $\mathrm{Mo}_{2} \mathrm{FeB}_{2}$ particles are beneficial to the increase of fracture toughness of cermets. The relative amount of $\mathrm{Fe}$ binder phase and relative density of cermets both decrease with Ti content increasing, which is harmful to fracture toughness. The factor favorable to the improvement of fracture toughness is that $\mathrm{Mo}_{2} \mathrm{FeB}_{2}$ particles become equiaxed. On the whole, the negative effects predominate with the increase of fracture toughness. Thus, the fracture toughness decreases with increasing Ti content. 
Figure 11 displays the TRS of cermets with various Ti contents and the corresponding fractograph after three-point bending tests. In the bending fracture surface morphology images, the tearing edge, pullout, transgranular fracture, and pore are marked with dotted circles in different colors. This line chart shows that with the increase of Ti content from $0 \mathrm{wt} . \%$ to $1.5 \mathrm{wt} . \%$, the TRS first increases and then decreases. The maximum TRS of $1612.6 \mathrm{MPa}$ occurs at $1.0 \mathrm{wt} . \%$ Ti content. As Ti content is between $0 \mathrm{wt} . \%$ and $1.0 \mathrm{wt} . \%$, fine grained, equably distributed, and equiaxed $\mathrm{Mo}_{2} \mathrm{FeB}_{2}$ particles are beneficial to the improvement of TRS. The uniform distribution of $\mathrm{Mo}_{2} \mathrm{FeB}_{2}$ particles makes the stress scatter in more particles under bend deformation, resulting in more uniform deformation [44,45]. Meanwhile, the equiaxed $\mathrm{Mo}_{2} \mathrm{FeB}_{2}$ particles also reduce the stress concentration. Furthermore, due to the equiaxed $\mathrm{Mo}_{2} \mathrm{FeB}_{2}$ particles, the microcracks are more likely to propagate in the Fe binder phase, which absorbs a lot of energy and leads to the improvement of TRS of $\mathrm{Mo}_{2} \mathrm{FeB}_{2}$-based cermets. Additionally, presence of equiaxed $\mathrm{Mo}_{2} \mathrm{FeB}_{2}$ hard phase in cermets will change the direction of crack propagation, causing the crack bridging, branching and deflection [46,47]. As shown in the fracture surface with 0 wt.\% and $1.0 \mathrm{wt} . \%$ Ti contents, less pores are observed in cermets without $\mathrm{Ti}$, which shows good densification of cermets. More tearing edges generated by the plastic deformation of $\mathrm{Fe}$, are observed in cermets with 1.0 wt.\% Ti content, indicating that cermets consume more energy in the process of fracture. Besides, more transgranular fracture is observed, which shows a firm interfacial binding and an increase of TRS. When Ti content is $1.5 \mathrm{wt}$ \%, the decrease of the relative density of cermets and agglomeration growth of $\mathrm{Mo}_{2} \mathrm{FeB}_{2}$ hard phase cause the big drop in TRS. The low relative density of cermets can increase the amount of pores, resulting in a stress concentration. The large size of $\mathrm{Mo}_{2} \mathrm{FeB}_{2}$ grains caused by grain agglomeration is not conducive to the TRS of cermets as per the Hall-Petch theory. As shown in fractograph of $1.5 \mathrm{wt}$ \% Ti content, more pores are seen in cermets, indicating more stress concentration and are more easily ruptured. In addition, more pullout, which is determined by interfacial bonding strength between $\mathrm{Mo}_{2} \mathrm{FeB}_{2}$ and $\mathrm{Fe}$, is also observed in cermets. These results show that the wettability of $\mathrm{Fe}$ on $\mathrm{Mo}_{2} \mathrm{FeB}_{2}$ particles is poor, which is not conducive to TRS improvement.

\section{Ti content / wt. $\%$}

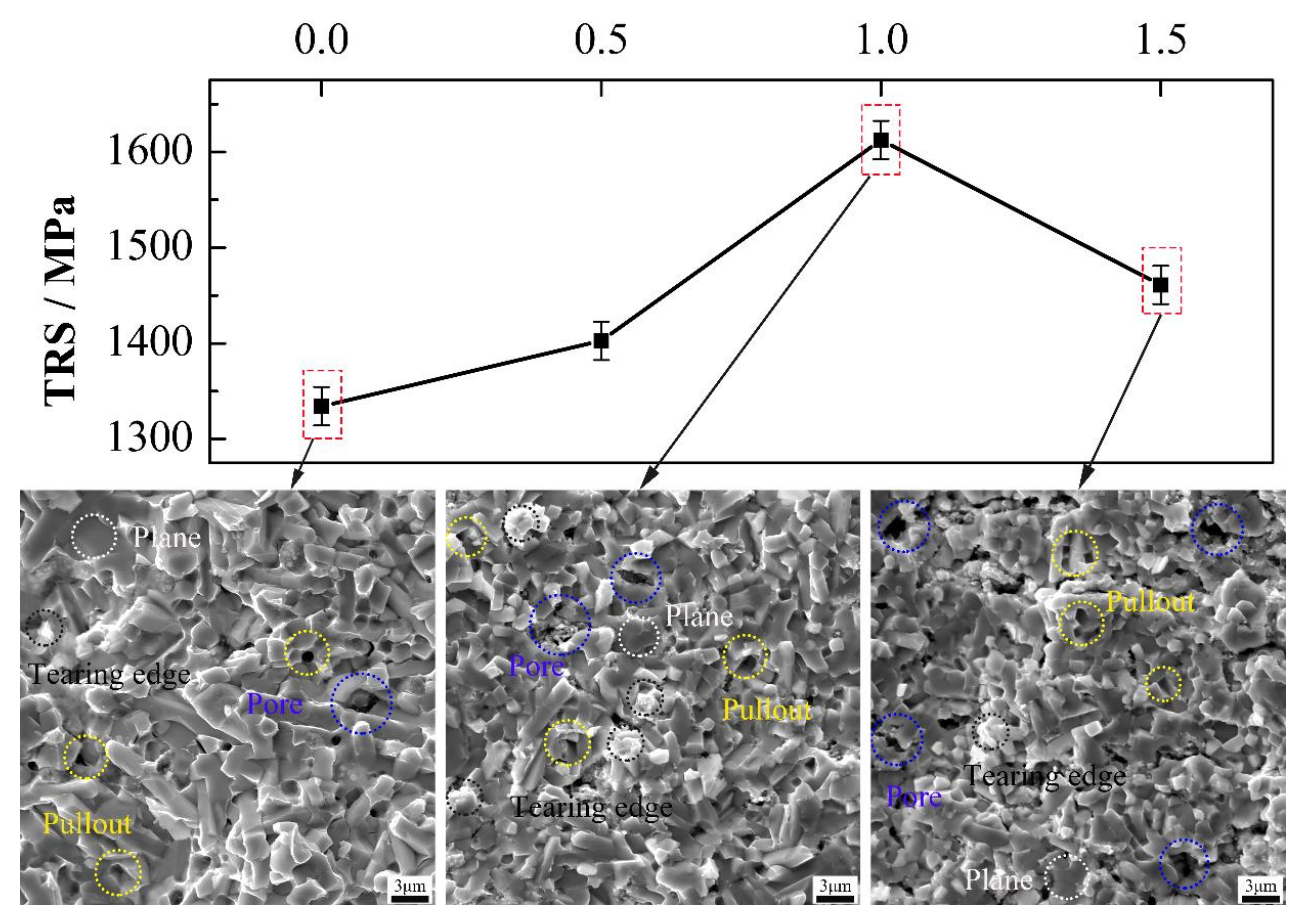

Figure 11. TRS of $\mathrm{Mo}_{2} \mathrm{FeB}_{2}$-based cermets and corresponding fractograph after three-point bending tests with different Ti contents. 


\section{Conclusions}

(1) The addition of Ti increases temperatures of forming liquid phases in the sintering process.

(2) Ti elements are mainly distributed in $\mathrm{Mo}_{2} \mathrm{FeB}_{2}$ and Ti atoms replace a fraction of Mo atoms in $\mathrm{Mo}_{2} \mathrm{FeB}_{2}$. The solution of Ti atoms causes the $\mathrm{Mo}_{2} \mathrm{FeB}_{2}$ crystal to be equiaxed. When Ti content is $1.0 \mathrm{wt} . \%$, the cermets exhibit the smallest particle size. Moreover, the solution of $\mathrm{Ti}$ atoms in $\mathrm{Mo}_{2} \mathrm{FeB}_{2}$ promotes the transformation of $\mathrm{Mo}_{2} \mathrm{FeB}_{2}$ particles from elongated shape to equiaxed shape.

(3) With Ti content increasing from $0 \mathrm{wt} . \%$ to $1.5 \mathrm{wt} . \%$, the hardness and TRS first increase and then decrease. The maximum hardness and TRS occur with $1.0 \mathrm{wt} . \%$ Ti content. However, the fracture toughness decreases with Ti content increasing. The cermets with $1.0 \mathrm{wt} . \%$ Ti content show the excellent comprehensive mechanical properties, and the hardness, fracture toughness, and TRS are HRA 89.5, 12.9 $\mathrm{MPa} \cdot \mathrm{m}^{1 / 2}$, and $1612.6 \mathrm{MPa}$, respectively.

Supplementary Materials: The following are available online at http:/www.mdpi.com/1996-1944/13/8/1889/s1, Figure S1: Sintering curve of $\mathrm{Mo}_{2} \mathrm{FeB}_{2}$-based cermets.

Author Contributions: Literature search: Y.S., K.L. and Z.C.; figures: Y.S.; data collection: Y.S. and L.Z.; data analysis: Y.S., L.Z. and P.X.; writing: Y.S. and Y.J.; study design: Z.H.; data interpretation: Y.J. All authors have read and agreed to the published version of the manuscript.

Funding: This research was supported by the National Natural Science Foundation of China (51571159) and China Postdoctoral Science Foundation (Grant No. 2019M663700).

Conflicts of Interest: The authors declare no conflict of interest.

\section{References}

1. Ghafuri, F.; Ahmadian, M.; Emadi, R.; Zakeri, M. Effects of SPS parameters on the densification and mechanical properties of $\mathrm{TiB}_{2}-\mathrm{SiC}$ composite. Ceram. Int. 2019, 45, 10550-10557. [CrossRef]

2. Li, X.; Gao, Y.; Song, L.; Yang, Q.; Wei, S.; You, L.; Zhou, Y.; Zhang, G.; Xu, L.; Yang, B.; et al. Influences of $\mathrm{hBN}$ content and test mode on dry sliding tribological characteristics of $\mathrm{B}_{4} \mathrm{C}-\mathrm{hBN}$ ceramics against bearing steel. Ceram. Int. 2018, 44, 6443-6450. [CrossRef]

3. Li, X.; Wei, S.; Yang, Q.; Gao, Y.; Zhong, Z. Tribological performance of self-matching pairs of $\mathrm{B}_{4} \mathrm{C} / \mathrm{hBN}$ composite ceramics under different frictional loads. Ceram. Int. 2020, 46, 996-1001. [CrossRef]

4. Yu, H.; Liu, W.; Zheng, Y. Microstructure and mechanical properties of liquid phase sintered $\mathrm{Mo}_{2} \mathrm{FeB}_{2}$ based cermets. Mater. Des. 2011, 32, 3521-3525. [CrossRef]

5. Takagi, K.I. High tough boride base cermets produced by reaction sintering. Mater. Chem. Phys. 2001, 67, 214-219. [CrossRef]

6. Yuan, B.; Zhang, G.-J.; Kan, Y.-M.; Wang, P.-L. Reactive synthesis and mechanical properties of $\mathrm{Mo}_{2} \mathrm{NiB}_{2}$ based hard alloy. Int. J. Refract. Met. Hard Mater. 2010, 28, 291-296. [CrossRef]

7. Zhang, L.; Huang, Z.; Liu, Y.; Shen, Y.; Li, K.; Cao, Z.; Ren, Z.; Jian, Y. Effect of Ni content on the microstructure, mechanical properties and erosive wear of $\mathrm{Mo}_{2} \mathrm{NiB}_{2}-\mathrm{Ni}$ cermets. Ceram. Int. 2019, 45, 19695-19703. [CrossRef]

8. Zhang, L.; Huang, Z.F.; Shen, Y.P.; Li, K.M.; Cao, Z.; Jian, Y.X.; Ren, Z.J. High-temperature compressive properties and tribological behaviour of $\mathrm{Mo}_{2} \mathrm{NiB}_{2}-\mathrm{Ni}$ cermets. Ceram. Int. 2019, 45, 18413-18421. [CrossRef]

9. Zhang, T.; Yin, H.; Zhang, C.; Zhang, R.; Yang, Z.; Elder, S.; Jiang, X.; Deng, Z.; Yang, G.; Zheng, Q.; et al. Synthesis and microstructure evolution of WCoB based cermets during spark plasma sintering. Ceram. Int. 2019, 45, 17536-17544. [CrossRef]

10. Zhang, L.; Huang, Z.; Liu, Y.; Shen, Y.; Li, K.; Cao, Z.; Ren, Z.; Jian, Y. Effects of mechanical ball milling time on the microstructure and mechanical properties of $\mathrm{Mo}_{2} \mathrm{NiB}_{2}-\mathrm{Ni}$ cermets. Materials 2019, 12, 1926. [CrossRef]

11. Haizhou, Y.; Wenjun, L.; Ping, F.; Yong, Z. Synthesis and microstructure evolution during vacuum sintering of $\mathrm{Mo}_{2} \mathrm{FeB}_{2}$ based cermets. Int. J. Refract. Met. Hard Mater. 2014, 45, 48-52. [CrossRef]

12. Peng, J.S.; Pan, Y.J.; Zhang, H. The influence of heat treatment on the interface and properties of $\mathrm{Mo}_{2} \mathrm{FeB}_{2}$ cermets-steel clad materia. Appl. Mech. Mater. 2014, 541-542, 199-203. [CrossRef] 
13. Wang, H.Q.; Sun, J.S.; Li, C.N.; Geng, S.N.; Sun, H.G.; Wang, G.L. Microstructure and mechanical properties of molybdenum-iron-boron-chromium cladding using argon arc welding. Mater. Sci. Technol. 2016, 32, 1694-1701. [CrossRef]

14. Yamasaki, Y.; Nishi, M.; Takagi, K.-I. Development of very high strength $\mathrm{Mo}_{2} \mathrm{NiB}_{2}$ complex boride base hard alloy. J. Solid State Chem. 2004, 177, 551-555. [CrossRef]

15. Takagi, K.-I. Development and application of high strength ternary boride base cermets. J. Solid State Chem. 2006, 179, 2809-2818. [CrossRef]

16. Ren, X.; Yu, L.; Liu, Y.; Li, H.; Wu, J.; Liu, Z. Effects of extra boron addition on the liquid-state sintering process and properties of hard $\mathrm{Mo}_{2} \mathrm{FeB}_{2}$-based cermets. Int. J. Refract. Met. Hard Mater. 2016, 61, 207-214. [CrossRef]

17. Shen, Y.; Huang, Z.; Jian, Y.; Yang, M.; Li, K. Investigation on microstructure and mechanical properties of $\mathrm{Mo}_{2} \mathrm{FeB}_{2}$ based cermets with and without PVA. Mater. Res. Express 2018, 5. [CrossRef]

18. Shen, Y.; Huang, Z.; Zhang, L. Effect of milling time on the microstructure and mechanical properties of $\mathrm{Mo}_{2} \mathrm{FeB}_{2}$ based cermets. Mater. Res. Express 2017, 4. [CrossRef]

19. He, L.; Gao, Y.; Li, Y.; Liu, Z.; Zhai, W.; Yuan, W.; Chen, W.; Yan, W. An effective way to solve the abnormal oxidation behavior of Fe in Ti(C,N)-304ss cermet. Corros. Sci. 2019, 155, 164-172. [CrossRef]

20. Yu, H.; Zheng, Y.; Liu, W.; Zheng, J.; Xiong, W. Effect of V content on the microstructure and mechanical properties of $\mathrm{Mo}_{2} \mathrm{FeB}_{2}$ based cermets. Mater. Des. 2010, 31, 2680-2683. [CrossRef]

21. Pang, X.; Zheng, Y.; Wang, S.; Wang, Q. Effect of Mn on valence-electron structure and properties of hard phase in $\mathrm{Mo}_{2} \mathrm{FeB}_{2}$-based cermets. Int. J. Refract. Met. Hard Mater. 2009, 27, 777-780.

22. Yang, F.; Wu, Y.; Han, J.; Meng, J. Microstructure, mechanical and tribological properties of $\mathrm{Mo}_{2} \mathrm{FeB}_{2}$ based cermets with Mn addition. J. Alloy. Compd. 2016, 665, 373-380. [CrossRef]

23. Yu, H.; Zheng, Y.; Liu, W.; Zheng, J.; Xiong, W. Effect of Mn content on the microstructure and mechanical properties of $\mathrm{Mo}_{2} \mathrm{FeB}_{2}$ based cermets. Int. J. Refract. Met. Hard Mater. 2010, 28, 286-290. [CrossRef]

24. Wang, S.; Pan, Y.; Lin, Y.; Tong, C. Influence of doping concentration on mechanical properties of $\mathrm{Mo}_{2} \mathrm{FeB}_{2}$ alloyed with $\mathrm{Cr}$ and $\mathrm{Ni}$ from first-principle calculations. Comput. Mater. Sci. 2018, 146, 18-25. [CrossRef]

25. Zhang, J.; Zheng, Y.; Zhou, W.; Zhang, G.; Ke, Z.; Dong, Z.; Feng, P. Effects of Cr content on the microstructure and mechanical properties of $\mathrm{Mo}_{2} \mathrm{FeB}_{2}$-based cermets prepared via vacuum sintering. Vacuum 2018, 155, 509-513. [CrossRef]

26. Dean, J.A. Lange's handbook of chemistry. Adv. Manuf. Process. 2010, 5, 687-688. [CrossRef]

27. Gladyshevskii, E.I.; Fedorov, T.F.; Kuz'Ma, Y.B.; Skolozdra, R.V. Isothermal section of the molbdenum-iron-boron system. Sov. Powder Metall. Met. Ceram. 1966, 5, 305-309.

28. Akopov, G.; Yin, H.; Roh, I.; Pangilinan, L.E.; Kaner, R.B. Investigation of hardness of ternary borides of the $\mathrm{YCrB}_{4}, \mathrm{Y}_{2} \operatorname{ReB}_{6}, \mathrm{Y}_{3} \operatorname{ReB}_{7}$, and $\mathrm{YMo}_{3} \mathrm{~B}_{7}$ structural types. Chem. Mater. 2018, 30, 6494-6502. [CrossRef]

29. Ramachandran, R.; Salguero, T.T. Nanostructuring of strontium hexaboride via lithiation. Inorg. Chem. 2018, 57, 4-7. [CrossRef]

30. Cahill, J.T.; Alberga, M.; Bahena, J.; Pisano, C.; Borja-Urby, R.; Vasquez, V.R.; Edwards, D.; Misture, S.T.; Graeve, O.A. Phase stability of mixed-cation alkaline-earth hexaborides. Cryst. Growth Des. 2017, 17, 3450-3461. [CrossRef]

31. Verger, L.; Kota, S.; Roussel, H.; Ouisse, T.; Barsoum, M.W. Anisotropic thermal expansions of select layered ternary transition metal borides: $\mathrm{MoAlB}, \mathrm{Cr}_{2} \mathrm{AlB}_{2}, \mathrm{Mn}_{2} \mathrm{AlB}_{2}$, and $\mathrm{Fe}_{2} \mathrm{AlB}_{2}$. J. Appl. Phys. 2018, 124. [CrossRef]

32. Lee, D.D.; Kang, S.J.L.; Yoon, D.N. Mechanism of grain growth and $\alpha-\beta^{\prime}$ Transformation during liquid-Phase sintering of $\beta^{\prime}$-Sialon. J. Am. Ceram. Soc. 1988, 71, 803-806. [CrossRef]

33. Ren, X.; Fu, H.; Xing, J.; Yi, Y. Effect of solidification rate on microstructure and toughness of Ca-Ti modified high boron high speed steel. Mater. Sci. Eng. A 2018, 742, 617-627. [CrossRef]

34. Huang, Z.; Xing, J.; Gao, Y. Effect of boron on the microstructure and properties of semisolid hypereutectic high chromium cast iron. Rare Met. Mater. Eng. 2011, 40, 244-247.

35. Wang, J.; Xing, J.; Qiu, Z.; Zhi, X.; Cao, L. Effect of fabrication methods on microstructure and mechanical properties of $\mathrm{Fe}_{3} \mathrm{Al}$-based alloys. J. Alloy. Compd. 2009, 488, 117-122. [CrossRef]

36. Ide, T.; Ando, T. Reaction sintering of an Fe- 6 wt pct B- 48 wt pct Mo alloy in the presence of liquid phases. Metall. Trans. A 1989, 20, 17-24. [CrossRef] 
37. Bo, H.; Wang, J.; Duarte, L.; Leinenbach, C.; Liu, L.-B.; Liu, H.-S.; Jin, Z.-P. Thermodynamic re-assessment of Fe-Ti binary system. Trans. Nonferr. Metal. Soc. China 2012, 22, 2204-2211. [CrossRef]

38. Cacciamani, G.; De Keyzer, J.; Ferro, R.; Klotz, U.E.; Lacaze, J.; Wollants, P. Critical evaluation of the Fe-Ni, $\mathrm{Fe}-\mathrm{Ti}$ and Fe-Ni-Ti alloy systems. Intermetallics 2006, 14, 1312-1325. [CrossRef]

39. Huang, P. Principles of Powder Metallurgy; Metallurgical Industry Press: Beijing, China, 1997.

40. Meredith, B.; Milner, D.R. Densification mechanisms in the tungsten carbide-Cobalt system. Powder Metall. 1976, 19, 38-45. [CrossRef]

41. Bhaumik, S.K.; Upadhyaya, G.S.; Vaidya, M.L. Full density processing of complex WC-based cemented carbides. J. Mater. Process. Technol. 1996, 58, 45-52. [CrossRef]

42. Choi, K.; Hwang, N.M. Effect of VC addition on microstructural evolution of WC-Co alloy: Mechanism of grain growth inhibition. Powder Metall. 2000, 43, 168-172. [CrossRef]

43. Lee, H.R.; Kim, D.J.; Hwang, N.M.; Kim, D.-Y. Role of vanadium carbide additive during sintering of WC-Co: Mechanism of grain growth inhibition. J. Am. Ceram. Soc. 2003, 86, 152-154. [CrossRef]

44. Zhang, Q.; Liu, B.; Niu, Z.; Zhang, Z.; Leng, Z. Grain refinement and mechanical properties of Mg-5Li-3Al alloy inoculated by Al-5Ti-1B master alloy. Mater. Sci. Eng. A 2014, 619, 152-157. [CrossRef]

45. Fang, C.; Liu, G.; Hao, H.; Zhang, X. Effects of particle distribution on microstructural evolution and mechanical properties of $\mathrm{TiB}_{2} / \mathrm{AZ} 31$ composite sheets. Mater. Sci. Eng. A 2017, 684, 592-597. [CrossRef]

46. Tian, K.; Zhao, Y.; Jiao, L.; Zhang, S.; Zhang, Z.; Wu, X. Effects of in situ generated ZrB ${ }_{2}$ nano-particles on microstructure and tensile properties of 2024Al matrix composites. J. Alloy. Compd. 2014, 594, 1-6. [CrossRef]

47. Xiao, P.; Gao, Y.; Yang, C.; Liu, Z.; Li, Y.; Xu, F. Microstructure, mechanical properties and strengthening mechanisms of $\mathrm{Mg}$ matrix composites reinforced with in situ nanosized $\mathrm{TiB}_{2}$ particles. Mater. Sci. Eng. A 2018, 710, 251-259. [CrossRef]

(C) 2020 by the authors. Licensee MDPI, Basel, Switzerland. This article is an open access article distributed under the terms and conditions of the Creative Commons Attribution (CC BY) license (http://creativecommons.org/licenses/by/4.0/). 